\title{
KEMAMPUAN SPASIAL SISWA SMP DALAM MEMECAHKAN MASALAH GEOMETRI RUANG BERDASARKAN KECERDASAN SPASIAL DAN KECERDASAN LOGIKA
}

\author{
Siti Faizah \\ Program Studi Pendidikan Matematika, Fakultas Ilmu Pendidikan, Universitas Hasyim Asy’ari \\ izahfaiz90@yahoo.co.id
}

\begin{abstract}
Abstrak
Matematika merupakan mata pelajaran yang penting, sehingga matematika diajarkan pada tingkat SD sampai perguruan tinggi. Salah satu materi yang diajarkan pada siswa sejak SD adalah tentang geometri, kemudian pada tigkat SMP materi tersebut dikembangkan menjadi geometri ruang. Dalam mempelajari geometri ruang tidak terlepas dari kemampuan spasial karena kemampuan spasial merupakan kemampuan untuk menghasilkan, menyimpan, mengambil dan mengubah gambar tiga dimensi yang terstruktur dengan baik. Sehingga kemampuan spasial siswa SMP dalam memecahkan masalah geometri ruang yakni siswa mampu berusaha mengembangkan kemampuan penginderaan spasialnya yang sangat berguna dalam memahami relasi dan sifat-sifat dalam geometri untuk memecahkan masalah matematika dan masalah dalam kehidupan sehari-hari serta dapat menumbuhkan kemampuan berfikir logis, mengembangkan kemampuan memecahkan masalah dan pemberian alasan.
\end{abstract}

Kata Kunci: Kemampuan spasial, geometri ruang, kecerdasan spasial dan kecerdasan logika

\begin{abstract}
Mathematics is very important lesson, so that mathematics is taught in primary school up to college. One of the material that is taught to students in elementary school is about geometry, then at the junior high school the material is developed into space geometry. In studying the geometry of space, it is inseparable from spatial abilities because spatial ability is the ability to generate, store, retrieve and change the three-dimensional image that is well structured. So that spatial ability of junior high school students in problem solving of spatial geometry of space that students can try to develop spatial sensing capabilities that are very useful in understanding relation and characteristics in geometry to solve mathematics problems and problems in daily activity. While the spatial ability of junior high school students whose logical intelligence in solving space geometry problems by studying geometry can foster the logical thinking ability, develop problem-solving skills and reasoning.
\end{abstract}

Keyword: spatial ability, geometry of space, spatial intelligence and logical intelligence.

\section{PENDAHULUAN}

Kemampuan merupakan suatu upaya yang dimiliki setiap manusia untuk melakukan segala sesuatu dalam kehidupan sehari-hari, misalnya seseorang ingin mengendarai mobil, seseorang ini tidak bisa langsung mengendarai mobil tanpa memiliki kemampuan mengendarai mobil terlebih dahulu. Begitu juga dengan matematika, seseorang bisa mmemahami matematika jika seseorang itu mempunyai kemampuan terhadap matematika. Matematika merupakan salah satu ilmu yang telah mengalami perkembangan baik dari segi materi maupun penerapannya. Matematika menempati posisi utama dalam kelangsungan hidup manusia karena dalam keseluruhan aktivitas manusia hampir dapat dijumpai penerapan matematika didalamnya.

Pentingnya matematika tidak hanya meliputi dalam kehidupan manusia secara umum saja, tetapi juga mencakup dalam dunia pendidikan. Hal ini dapat dibuktikan dengan adanya mata pelajaran matematika sejak siswa duduk dibangku sekolah dasar hingga perguruan tinggi, tidak terkecuali pada tingkat Sekolah Menengah Pertama. Ada beberapa tujuan mengapa matematika itu dipelajari, sebagaimana disampaikan oleh Andi hakim nasution dalam Hasyim (2009:2) 
yaitu : 1) matematika dapat digunakan untuk mengetahui gejala-gejala alam, 2) dengan penggunaan metode matematika dapat diperhitungkan segala sesuatu dalam pengambilan keputusan, 3) matematika penting sebagai sains untuk perkembangan budaya bangsa, 4) matematika dapat digunakan dalam lapangan kerja, serta 5) melalui matematika seseorang dapat menyampaikan ide-ide secara benar, tepat jelas kepada orang lain.

Selain itu, pentignya matematika bagi siswa adalah sebagai alat untuk melatih cara berpikir dan bernalar dalam menarik kesimpulan serta mengembangkan kemampuan untuk memecahkan masalah dalam kehidupan sehari-hari. Hal ini sejalan dengan tujuan pembelajaran matematika di Sekolah Menengah Pertama yang tercantum dalam kurikulum tingkat satuan pendidikan (KTSP) yaitu supaya siswa memiliki kemampuan sebagai berikut: (Depdiknas : 2006)

1. Memahami konsep matematika, menjelaskan keterkaitan antar konsep dan mengaplikasikan konsep atau algoritma secara luwes, akurat, efisien, dan tepat dalam pemecahan masalah;

2. Menggunakan penalaran pada pola pikir dan sifat, melakukan manipulasi matematika dalam membuat generalisasi, menyusun bukti, atau menjelaskan gagasan dan pernyataan matematika;

3. Memecahkan masalah yang meliputi kemampuan memahami masalah, merancang model matematika, menyelesaikan model dan menafsirkan solusi yang diperoleh;

4. Mengkomunikasikan gagasan dengan simbol, tabel, diagram, atau media lain untuk memperjelas keadaan atau masalah;

5. Memiliki sikap menghargai kegunaan matematika dalam kehidupan, yaitu memiliki rasa ingin tahu, perhatian dan minat dalam mempelajari matematika, serta sikap ulet dan percaya diri dalam pemecahan masalah.

Belajar matematika merupakan salah satu bagian dari pendidikan agar memperoleh pengertian tentang hubungan dan simbol yang kemudian dapat diaplikasikan ke dalam dunia nyata. Salah satu cabang matematika yang dipelajari dan dapat diaplikasikan dalam dunia nyata yaitu Geometri ruang, karena geometri sudah dikenal siswa sejak sebelum masuk sekolah. Sehingga dengan adanya materi geometri ini siswa mampu menggunakan kemampuan logikanya untuk berpikir dalam bentuk gambar.

Dengan adanya materi geometri ini dapat membantu siswa melatih cara berpikir dan bernalar, salah satunya yakni dengan menggunakan kemampuan spasial. Sehigga menurut Hodward Gardne (2009:3) mengemukakan bahwa Intelegensi ada 8 jenis (Multiple Intelegensi) salah satunya yakni kecerdasan spasial. Konsep tentang berpikir spasial cukup menarik untuk dibahas mengingat banyak penelitian sebelumya yang menyatakan bahwa anak menemukan banyak kesulitan untuk memahami obyek atau gambar bangun geometri. Berpikir spasial merupakan kumpulan dari ketrampilan kognitif, yaitu terdiri dari gabungan tiga unsur yang meliputi: konsep keruangan, alat representasi, dan proses penalaran.

Dalam geometri, kemampuan spasial mempunyai peranan yang sangat penting untuk ditingkatkan. Hal ini mengacu dari hasil penelitian (National of Scince (2006:3) yang mengemukakan bahwa setiap siswa harus berusaha mengembangkan kemampuan dan kompetensi spasialnya serta dengan menggunakan kecerdasan logikanya yang sangat berguna dalam memahami relasi dan sifat-sifat dalam geometri untuk memecahkan masalah matematika khususnya masalah geometri ruang.

Menurut Pavani Rynhart keterampilan spasial merupakan kemampuan untuk menghasilkan, menyimpan, mengambil dan mengubah gambar tiga dimensi yang terstruktur dengan baik. Sedangkan dalam sistem pendidikan di sekolah, geometri merupakan salah satu materi pada mata pelajaran matematika yang sulit untuk dipelajari siswa, karena hal ini membutuhkan 
kecerdasan spasial untuk memecahkan masalah geometris spasial.

Spatial skills may be defined as the ability to generate, retain, retrieve and transform wellstructured 3-dimensional images. Secondary school mathematics, geometry is one of the more difficult subjects to learn for many, it requires visual or spatial intelligence to solve spatial geometric problems (2012:5).

Berdasarkan uraian diatas maka tujuan dari penulisan ini adalah untuk mendeskripsikan cara meningkatkan kemampuan spasial siswa SMP yang keceradasannya spasial dalam memecahkan masalah geometri ruang, serta untuk mendeskripsikan cara menigkatkan kemampuan spasial siswa SMP yang kecerdasannya logika dalam memecahkan masalah geometri ruang.

Sedangkan manfaat dalam penulisan ini adalah dapat memberikan sumbangan pemikiran bagi perkembangan ilmu pengetahuan, khususnya dalam bidang matematika yang nantinya dapat digunakan sebagai acuan dan pedoman dalam kegiatan belajar mengajar. Serta dapat menumbuhkan kemampuan dan kecerdasan siswa dalam belajar matematika khususnya dalam materi geometri, serta dapat dijadikan alternatif pilihan bagi guru sebagai upaya peningkatan kecerdasan siswa.

\section{PEMBAHASAN}

\section{Kemampuan Spasial}

Pengertian spasial yang dikemukakan oleh para pakar pada umumnya memberikan penekanan pada gambar tiga dimensi atau tentang ruang. Menurut Pavani Rynhart (2012:6) kemampuan spasial diartikan kemampuan untuk menghasilkan, menyimpan, mengambil dan mengubah gambar tiga dimensi yang terstruktur dengan baik.

Menurut siti marliyah tambunan (2006:5) mengemukakan bahwa kemampuan spasial yaitu kemampuan tentang konsep abstrak yang meliputi persepsi spasial yang melibatkan hubungan spasial termasuk orientasi sampai pada kemampuan yang rumit yang melibatkan manipulasi serta rotasi mental.

Sedangkan menurut Howard Gardner (2009:5) menyatakan bahwa kemampuan spasial yaitu kemampuan untuk membentuk dan menggunakan model mental. Seseorang yang memiliki kemampuan ini cenderung berpikir dengan menggunakan bentuk gambar, video, dan pergaan yang menggunakan model.

Kemampuan spasial mempunyai peranan yang penting untuk menyelesaikan tugas dalam kehidupan sehari-hari. Misalnya, dengan menggunakan peta untuk mencari letak kota yang asing, parkir mobil, orientasi diri dalam lingkungan, hal ini merupakan kegiatan yang umum dilakukan dengan menggunakan kemampuan spasial. Dengan menggunakan kemampuan spasial siswa mampu belajar secara naluriah, misalnya siswa mempunyai rasa ingin tahu tentang menuangkan benda cair (air, butiran halus , dll) ke dalam wadah dari berbagai bentuk dan ukuran, sehingga hal ini bisa meningkatkan kemampuan motorik siswa untuk berusaha mencari volume dari benda cair yang dimasukkan kedalam wadah tersebut. Hal ini sesuai dengan yang dinyatakan oleh Pavani Rynhart

"Spatial skills are of great importance for solving many tasks in everyday life. For instance, using a map to guide through an unfamiliar city, parking a car, orienting oneself in the environment, packing boxes or bags, or even using a mirror are common activities that are solved using spatial thinking. The use of spatial skills however, begins much younger. Children learn spatial skills instinctively and this can be observed when we notice them knocking over things when they are running or walking in the early years of their life's. Some also have the curiosity of pouring matter that is fluid (water, fine grains, etc.) into containers of 
various sizes. Apart from improving their motor skills they are also exploring sizes and volumes of various shapes of containers" (2012:4).

Berdasarkan pengertian-pengertian yang telah dikemukakan oleh beberapa pakar tersebut, maka dalam hal ini penulis mendefinisikan bahwa kemampuan spasial adalah kemampuan yang terstruktur dengan baik dengan menggunakan bentuk gambar, video, dan pergaan yang menggunakan model.

\section{Kecerdasan Spasial}

\section{Pengertian Kecerdasan}

Menurut Suharnan (2005:15) kecerdasan adalah kemampuan mental, pikiran atau intelektual manusia. Secara umum kecerdasan sering disebut dengan intelegensi, sehingga seseorang yang memiliki intelegensi tinggi sering disebut pula sebagai orang cerdas atau jenius. Sehingga kecerdasan diartikan sebagai kemampuan memperoleh dan menggali pengetahuan, menggunakan pengetahuan untuk memahami konsep-konsep konkret dan abstrak, dan menghubungkan di antara obyek-obyek dan gagasan-gagasan, menggunakan cara-cara yang lebih berguna (in a meaningful way) atau efektif.

Menurut Rendik Widiyanto dan Badiatur Rofiah (2012:4) menyebutkan bahwa kecerdasan adalah kemampuan untuk menangkap situasi baru serta kemampuan untuk belajar dari pengalaman masa lalu seseorang. Menurut Howard Gadner (2009:3) seorang psikolog Amerika mengatakan bahwa kecerdasan adalah kemampuan menghasilkan produk dalam suatu setting yang bermacam-macam dan situasi yang nyata.

Kecerdasan merupakan kemampuan untuk belajar dari pengalaman masa lalu. Serta kecerdasan dapat pula diartikan sebagai kemampuan seseorang untuk menguasai kemampuan tertentu atas aneka macam ketrampilan. Sehingga menurut Howard
Gardner (2009:5) mengidentifikasikan tujuh kecerdasan yang harus dikembangkan, yakni:

a. Kecerdasan Linguistik, adalah kecerdasan dalam hal mengolah kata.

b. Kecerdasan logis matematis, adalah kecerdasan dalam hal angka dan logika. Kecerdasan ini memiliki kemampuan dalam hal penalaran, pengurutan, berfikir dalam pola sebab akibat, berhipotesa, keteraturan konseptual dan numerik serta berpandangan yang rasional.

c. Kecerdasan spasial adalah kecerdasan yang mencakup kemampuan berfikir dalam gambar, menyerap, mengubah dan menciptakan berbagai aspek dunia visual-spasial.

d. Kecerdasan musical, adalah kemampuan untuk menghargai dan menciptakan irama dan melodi.

e. Kecerdasan kinestik-jasmani, adalah kemampuan dalam hal mengendalikan gerak tubuh dan ketrampilan dalam menguasai benda.

f. Kecerdasan antar pribadi, adalah kemampuan untuk memahami dan bekerjasama dengan orang lain. Kecerdasan ini menuntut kemampuan untuk memahami orang lain dan melihat dunia dari sudut pandang orang yang bersangkutan.

g. Kecerdasan intrapribadi, adalah kecerdasan dalam diri sendiri. Kecerdasan ini akan memberikan kemampuan untuk mengakses perasaannya sendiri dan menangani berbagai macam emosi, serta kemampuan untuk mandiri dan disiplin.

Berdasarkan pendapat para pakar tentang kecerdasan diatas maka penulis mendefinisikan kecerdasan menurut Gadner seorang psikolog Amerika yang mengatakan bahwa kecerdasan adalah kemampuan menghasilkan produk dalam suatu setting yang bermacam-macam dan situasi yang nyata. 


\section{Pengertian Kecerdasan Spasial}

Menurut Suharnan (2005:20) kecerdasan spasial (spatial intelligence) adalah kemampuan untuk melihat dan memanipulasi pola-pola dan rancangan-rancangan. Seorang pelaut, insinyur, dokter bedah, pemahat, dan pelukis adalah contoh di antara mereka yang memiliki inteligensi ruang yang tinggi.

Menurut Julia Jasmine (2012:10) kecerdasan spasial yang kadang- kadang disebut kecerdasan visual atau visual-spasial, adalah kemampuan untuk membentuk dan menggunakan model mental. Orang yang memiliki kecerdasan jenis ini cenderung berpikir dalam atau dengan gambar dan cenderung mudah belajar melalui sajiansajian visual seperti film, gambar, video, dan peragaan yang menggunakan model slaid. Kecerdasan spasial sering dialami dan diungkapkan dengan berangan-angan, berimajinasi dan berperan. Kecerdasan ini dapat dilukiskan sebagai kegiatan otak-kanan dan mempunyai beberapa karakteristikyang mirip dengan kecerdasan intrapersonal.

Menurut Agus Efendi (2005:9) kecerdasan spasial merupakan kemampuan untuk memberikan gambar-gambar dan imaginasi-imaginasi, serta kemampuan dalam mentransformasikan dunia visualspasial. Keterampilan menghasilkan imaginasi mental dan meciptakan representasi grafis, berfikir tiga dimensi, mencipta ulang dunia visual. Sehingga pusat kecerdasan spasial adalah kemampuan mempersepsi dunia visual dengan akurat, mentransformasi dan memodifikasi pengalaman visual seseorang, bahkan ketika tidak ada rangsangan fisikal yang relevan.

Menurut Gardner dan Chen, Moran dan Gardner dalam Emilia Sarno (2012:10) menyatakan bahwa kecerdasan spasial dapat bermanifestasi sebagai bakat tertentu untuk berpikir dan berkomunikasi. Kecerdasan spasial didasarkan pada kemampuan untuk mengubah persepsi, mengatur informasi ke dalam peta kognitif yang jelas dan tepat. Menurut Maier (1998), kecerdasan spasial adalah kemampuan untuk bergerak di ruang angkasa, untuk mengorientasikan diri sendiri, dan untuk berpikir serta merencanakan.

Menurut Howard Gadner (2009:8) menguraikan deskripsi tentang kecerdasan spasial adalah kemampuan memahami, memproses, dan berpikir dalam bentuk visual. Siswa dengan kecakapan ini mampu menerjemahkan bentuk gambaran dalam pikirannya ke dalam bentuk dua atau tiga dimensi. Ciri khusus dari kecerdasan spasial adalah pemahaman tentang arah, serta berpikir dan merencanakan sesuatu dalam tiga dimensi. Ada lima jenis kemampuan visual spasial yaitu :

a. Hubungan keruangan (spasial relation)

Menunjukan persepsi tentang posisi berbagai objek dalam ruang. Dimensi fungsi visual ini mengimplikasikan persepsi tentang tempat suatu objek atau symbol (gambar, huruf, dan angka) hubungan ruangan yang menyatu dengan sekitarnya.

b. Diskriminasi visual (visual discrimination)

Menunjukan pada kemampuan membedakan suatu objek dari objek yang lain. Misalkan membedakan antara gambar balok dan kubus.

c. Diskriminasi bentuk latar belakang (Figure-ground discrimination)

Menunjukan pada kemampuan membedakan suatu objek dari latar belakang yang mengelilinginya. Anak memiliki kekurangan dalam bidang ini tidak dapat memusatkan perhatian pada suatu objek karena sekeliling objek tersebut ikut mempengaruhi perhatiannya.

\section{d. Visual Clouser}

Menunjukan pada kemampuan mengingat dan mengidentifikasi suatu objek, meskipun objek tersebut tidak diperhatikan secara keseluruhan.

e. Mengenal Objek (Object recognition)

Menujukan pada kemampuan mengenal sifat berbagai objek pada saat mereka memandang. Pengenalan tersebut mencakup berbagai bentuk geometri, huruf, angka dan sebagainya.

Berdasarkan pendapat para pakar, maka dalam hal ini penulis menggunakan pengertian menurut Menurut Howard Gadner (2009:6) yang menguraikan bahwa 
kecerdasan spasial adalah kemampuan memahami, memproses, dan berpikir dalam bentuk visual. Siswa dengan kecakapan ini mampu menerjemahkan bentuk gambaran dalam pikirannya ke dalam bentuk dua atau tiga dimensi. Ciri khusus dari kecerdasan spasial adalah pemahaman tentang arah, serta berpikir dan merencanakan sesuatu dalam tiga dimensi.

\section{Kecerdasan Logika}

Menurut Solso dalam Suharnan (2005:19) logika adalah ilmu pengetahuan tentang berpikir. Sementara itu berpikir adalah proses umum untuk mempertimbangkan berbagai isu di dalam pikiran manusia. Sedangkan menurut Ellis dan Hunt mendefinisikan logika adalah suatu perangkat aturan yang dengan aturan itu manusia dapat sampai pada suatu kesimpulan yang benar tentang sesuatu hal atau kejadian. Sehingga menurut Suharnan yang dimaksud logika yaitu suatu system berpikir formal yang didalamnya terdapat seperangkat aturan atau prinsip untuk menarik kesimpulan yang sahih dari premis-premis yang menjadi sumbernya.

Berdasarkan pada pembahasan tersebut maka dalam hal ini penulis mendefinisikan bahwa kecerdasan logika yaitu suatu kemampuan sistem berpikir formal yang didalamnya terdapat seperangkat aturan atau prinsip untuk menarik kesimpulan.

\section{Pemecahan Masalah}

Menurut polya (1973:95) masalah adalah suatu soal yang harus dipecahkan oleh seseorang terutama siswa tetapi cara/langkah untuk menyelesaikannya tidak segera ditemukan oleh siswa itu. Tetapi dalam suatu masalah sudah terkandung unsur-unsur yang diketahui dan unsur-unsur yang ditanyakan. Orang yang menghadapi soal itu harus berusaha menemukan cara untuk memecahkan soal tsb untuk memperoleh jawaban. Dari pengertian ini, suatu soal menjadi masalah atau bukan masalah bagi seseorang, merupakan hal yang bersifat relative. Artinya soal itu mungkin menjadi masalah bagi seseorang tetapi bagi orang lain itu mungkin bukan masalah.

$$
\text { Selanjutnya Polya }
$$

mengemukakan bahwa terdapat dua macam masalah dalam matematika, yaitu:

1. Masalah menemukan (problem to find) dapat berupa masalah teoritis atau praktis, abstrak atau konkrit, termasuk teka-teki. Bagian utama masalah ini adalah:bagaimana data yang diketahui dan bagaimana syaratnya, ketiga bagian utama tersebut merupakan landasan untuk dapat menyelesaikan masalah jenis ini.

2. Masalah membuktikan (problem to prove) bahwa suatu pertanyaan itu benar atau salah atau tidak keduanya. Bagian utama masalah jenis ini adalah hipotesis dan konklusi dari pernyataan yang harus dibuktikan kebenarannya. Kedua bagian utama ini perlu dikaji untuk dapat menyelesaiakn masalah jenis kedua ini.

Masalah untuk menemukan merupakan jenis masalah yang perlu diberikan kepada siswa SMP karena untuk melatih pemikiran mereka tentang proses bagaimana suatu konsep atau prinsip ditemukan. Selanjutnya Polya (1973:60) mengatakan bahwa masalah untuk menemukan lebih penting dalam matematika elementer, sedangkan masalah untuk membuktikan lebih penting dalam matematika lanjut.

Menurut anton (2011:25) pemecahan masalah adalah suatu proses yang dilakukan seseorang dalam menemukan jawaban suatu masalah matematika. Sedangkan yang dimaksud masalah matematika yaitu soal matematika yang dihadapi oleh seorang siswa, namun siswa tersebut tidak segera menemukan jalan/cara penyelesaiannya.

Menurut suharnan (2005: 9) pemecahan masalah adalah proses mencari dan menemukan jalan keluar terhadap suatu masalah atau kesulitan. Sedangkan krulik dan 
rudnik mendefinisikan pemecahan masalah adalah suatu cara yang dilakukan seseorang dengan menggunakan pengetahuan, keterampilan, dan pemahaman untuk memenuhi tuntutan dari situasi yang tidak rutin. Jadi pemecahan masalah adalah usaha seseorang untuk menyelesaikan suatu permaslahan menggunakan pengetahuan, keterampilan serta pemahaman yang dimilkinya.

Pemecahan masalah mempunyai peranan penting di dalam kegiatan belajar mengajar matematika. Melalui pemecahan masalah siswa dapat berlatih dan mengintegrasikan konsep-konsep, teorema-teorema dan keterampilan matematika yang dipelajari. Disamping itu menurut Cooney menyatakan bahwa dengan berlatih dalam pemecahan masalah siswa menjadi lebih analitis didalam mengambil keputusan di dalam hidupnya. Sehingga, dengan terbiasa memecahkan masalah matematika siswa dapat terlatih 4 mengambil keputusan yang cepat dan tepat dalam memecahkan masalah-masalah di sekitar kehidupannya.

Menurut Polya (1973:105) terdapat 4 langkah pokok dalam menyelesaikan masalah matematika, yaitu :

1. memahami masalah

Memahami masalah merupakan langkah yang sangat penting dalam menyelesaikan masalah. Tanpa memahami masalah dengan baik, sudah tentu seseorang tidak akan dapat menyelesaiakn masalah yang dihadapinya. Langkah ini dimulai dengan pengenalan apa yang diketahui atau informai yang tersedia. Selanjutnya data apa yang tersedia, kemudian melihat apakah data serta kondisi yang tersedia mencukupi untuk menentukan apa yang ditanyakan dari masalah yang diberikan.

2. menyusun rencana

Pada langkah ini diperlukan kemampuan untuk melihat hubungan antara data yang tersedia dengan data apa yang diketahui. Selanjutnya disusun sebuah rencana penyelesaian masalah, dengan memperhatikan hal-hal sebagai berikut: apakah siswa pernah menjumpai masalah itu sebelumnya; apakah siswa dapat menggunakan teorema untuk menyelsaikan masalah tersebut. Untuk masalah yang agak luas dapat diselesaikan bagian demi bagian dari masalah tersebut. Selanjutnya siswa dapat menyusun rencana dengan membuat sistematis langkah-langkah penyelesain.

3. melaksanakan rencana

Rencana penyelesaian yang telah dibuat sebelumnya, kemudian dilaksanakan secara cermat pada setiap langkah. Dalam melaksanakan rencana dapat membuat model matematika. Siswa diharapkan memperhatikan prinsip-prinsip (aturanaturan) pengerjaan yang ada untuk mendapat hasil yang benar. Untuk itu pengecekan pada setiap langkah harus selalu dilakukan untuk memastikan kebenaran jawaban.

memeriksa kembali

Pada langkah ini dilakukan untuk memastikan apakah penyelesaian tersebut sesuai dengan yang diinginkan dalam masalah itu atau tidak. Jika hasil yang diperoleh tidak sesuai, maka perlu pemeriksaan kembali atas setiap langkah yang telah dilakukan untuk mendapatkan hasil yang sesuai dengan masalah yang diberikan.

Sedangkan menurut Klurik dan Rudnik dalam Anton (2011:30) ada lima langkah yang dilakukan dalam pemecahan masalah, yaitu:

a. Membaca dan memikirkan (read and think)

Aktivitas yang dilakukan pada tahap ini adalah menganalisis masalah, menguji dan mengevaluasi fakta-fakta, menentukan pertanyaan, seting secara fisik yang divisualisasikan, dideskripsikan dan dipahami, masalah diterjemahkan ke dalam bahasa siswa dan menghubungkan anatara bagian-bagian dari masalah.

b. Mengeksplorasi dan merencanakan 


\section{(explore and plan)}

Aktivitas yang dilakukan pada tahap ini adalah menganalisis data dan menentukan syarat cukup suatu informasi, mengeliminasi ha-hal yang tidak perlu, mengorganisasikan data dalam suatu tabel, gambar atau model.

c. Memilih suatu strategi (select a strategy)

Strategi merupakn bagian penting dari proses pemecahan masalah untuk memberi arah atau petunjuk kepada siswa dalam menemukan jawabannya. Ada beberapa strategi yang umum digunakan dalam memecahkan masalah yaitu: (a) mengenal pola-pola (b) bekerja mjundur/balik (c) menerka dan menguji (d) melakukan percobaan dan simulasi (e) mereduksi atau memperluas (f) mengorganisasi daftar atau melengkapi daftar (g) merduksi seara logis (h) memisahkan dan mengatasi.

d. Menemukan suatu jawaban (find and answer)

Pada langkah ini semua keterampilanketerampilan matematika digunakan secara tepat untuk menemukan suatu jawaban. Lakukan perkiraan secara tepat, gunakan bantuan teknologi seperti kalkulator.

e. Meninjau kembali dan mendiskusikan (refrlect and extend)

Aktivitas yang dilakukan pada langkah ini adalah (a) mengecek jaawaban apakah perhitungan benar? Apakah pertanyaan terjawab? Apakah jawaban rasional? Bagaimana jawaban bika dibandingkan dengan hasil perkiraan? (b) menemukan alternative solusi, (c) membahas secara generalisasi atau kedalam konsep matematika yang lain, (d) mendiskusikan solusi-solusi, (e) menciptakan variasi-variasi yang menarik pada massalah semula.

Sedangkan langkah pemecahan masalah menurut Dewey swadener dalam Anton (2011:30) sebagai berikut:

1. Pengenalan (recognition) merasakan suatu kesulitan

2. Pendefinisian mengklasifikasi

(definition); karakteristik- kerakteristik dari situasi.

3. Perumusan (formulation); menyatakan dengan jelas hipotesis-hipotesis dan kondisi-kondisi

4. Mencobakan (test); melaksanakan rencana

5. Evaluasi (evaluation) apakah definisi masalah cocok dengan situasinya

Berdasarkan langkah-langkah pemecahan masalah yang dikemukakan diatas terlihat bahwa aktivitas pada langkah kedua dan ketiga dari Klurik dan Rudnik sama dengan langkah kedua pemecahan masalah Polya. Sedangkan aktivitas langkah pertama dan kedua dari Dewey sama dengan langkah pertama pemecahan masalah Polya. Perbandingan langkah-langkah pemecahan masalah dari ketiga pendapat di atas dirangkum pada tabel berikut:

Tabel 1. pengertian pemecahan masalah

\begin{tabular}{|c|c|c|}
\hline $\begin{array}{c}\text { Klurik dan } \\
\text { Rudnik (1995) }\end{array}$ & Polya (1973) & Dewey (1985) \\
\hline $\begin{array}{l}\text { Membaca dan } \\
\text { memikirkan (read } \\
\text { and think) } \\
\text { Mengeksplorasi } \\
\text { dan merencanakan } \\
\text { (explore and plan) } \\
\text { Memilih suatu } \\
\text { strategi (select a } \\
\text { strategy) } \\
\text { Menemukan suatu } \\
\text { jawaban (find and } \\
\text { answer) } \\
\text { Meninjau kembali } \\
\text { dan } \\
\text { mendiskusikan } \\
\text { (reflect and } \\
\text { extend) }\end{array}$ & $\begin{array}{l}\text { Memahami } \\
\text { masalah } \\
\text { (understands the } \\
\text { problem) } \\
\text { Membuat rencana } \\
\text { (devise a plan) } \\
\text { Melaksanakan } \\
\text { rencana (carry out } \\
\text { the plan) } \\
\text { Memeriksa } \\
\text { kembali (look } \\
\text { back) }\end{array}$ & $\begin{array}{l}\text { Pengenalan } \\
\text { (recognition) } \\
\text { Pendefinisian } \\
\text { (definition) } \\
\text { Perumusan } \\
\text { (formulation) } \\
\text { Mencobakan } \\
\text { (test) } \\
\text { Evaluasi } \\
\text { (evaluation) }\end{array}$ \\
\hline
\end{tabular}

Berdasarkan pembahasan tersebut maka dalam hal ini penulis menggunakan pengertian pemecahan masalah menurut suharnan yang menyatakan bahwa pemecahan massalah adalah proses mencari dan menemukan jalan keluar terhadap suatu masalah atau kesulitan. Sedangkan langkah langkah pemecahan masalah yang penulis gunakan yakni langkah-langkah pemecahan masalah menurut Polya, yakni terdapat empat langkah dalam pemecahan masalah. 


\section{Masalah Geometri Ruang}

Menurut Rendik Widiyanto dan Badiatur Rofiah (2012:5) Geometri ruang merupakan salah satu cabang matematika yang dapat menumbuhkan kemampuan siswa untuk dapat berfikir logis, mengembangkan kemampuan memecahkan masalah dan pemberian alasan serta dapat mendukung banyak topik lain dalam matematika. Geometri juga dapat diartikan dengan :

a. Cabang matematika yang mempelajari pola-pola visual,

b. Cabang matematika yang menghubungkan matematika dengan dunia fisik atau dunia nyata,

c. Suatu cara penyajian fenomena yang tidak tampak atau tidak bersifat fisik

d. Suatu contoh sistem matematika.

Bangun-bangun ruang pada dasarnya didapat dari benda-benda konkret dengan melakukan proses abstraksi dan idealisasi. Abstraksi adalah proses memperhatikan dan menentukan sifat, atribut ataupun karakteristik khusus dengan mengesampingkan hal-hal yang berbeda.

Sebagai salah satu contoh, dari bendabenda konkrit yang termasuk dalam geometri ruang yaitu potongan bambu, potongan hati batang pisang, kaleng minuman ataupun yang lainnya, proses berabstraksi terjadi ketika kita memperhatikan lalu mendapatkan hal-hal yang sama dari tiga macam benda konkret tersebut. Yang harus diperhatikan pada waktu siswa mengamati benda tersebut adalah bentuknya yang sama. Bentuk seperti potongan bambu, potongan hati batang pisang ataupun kaleng minuman itulah yang disebut dengan Tabung. Bentuk dan potongan benda-benda tersebut akan berbeda dengan bentuk benda-benda lainnya seperti batu bata ataupun tempat batang korek api, sehingga bentuk bangun ruang yang menyerupai batu bata ataupun tempat batang korek api tersebut tidak dikategorikan sebagai Tabung, namun diberi nama khusus lain, yaitu Balok.
Disamping proses abstraksi, proses yang sangat penting dalam geometri ruang adalah proses idealisasi. Idealisasi adalah proses menganggap segala sesuatu dari benda-benda konkret itu ideal. Misalnya yakni bentuk hati batang pisang yang agak melengkung sedikit, dianggap lurus tanpa cela. Batang bamboo yang agak tidak rata, harus dianggap rata.

Berkaitan dengan keabstrakan dari materi geometri ruang ini, Johson dan Rising (1987) dalam Hilaria Melania Mbagho (2012:25) menyatakan bahwa: "Mathematics is a creation of the human mind concerned primarily with ideas, processes, andreasoning". Yang berarti bahwa matematika merupakan kreasi pemikiran manusia yang pada intinya berkait dengan ide-ide, proses-proses dan penalaran.

Adapun obyek - obyek yang dibicarakan pada geometri ruang diantaranya adalah:

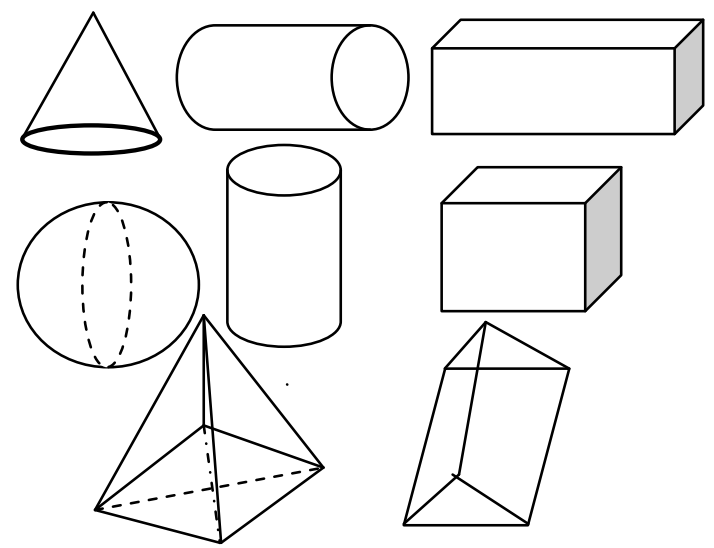

Gambar 1. Kerucut, Tabung, Kubus, Bola, Limas, dan Prisma.

Sehingga dalam hal ini penulis mengambil pengertian masalah geometri adalah cabang matematika yang mempelajari pola-pola visual, cabang matematika yang menghubungkan matematika dengan dunia fisik atau dunia nyata, suatu cara penyajian fenomena yang tidak tampak atau tidak bersifat fisik 


\section{Intellegent Spasial Siswa dalam Menyelesaikan Masalah Geometri Ruang}

Berdasarkan pada konteks kurikulum, NCTM (2000:99) mengemukakan bahwa terdapat lima standar isi dalam standar matematika, yaitu bilangan dan operasinya, pemecahan masalah, geometri, pengukuran, dan peluang serta analisis data. Geometri menempati posisi khusus dalam kurikulum matematika, karena banyaknya konsepkonsep yang termuat di dalamnya. Dari sudut pandang psikologi, geometri merupakan penyajian abstraksi dari pengalaman visual dan spasial, misalnya bidang, pola, pengukuran dan pemetaan. Sedangkan dari sudut pandang matematik, geometri menyediakan pendekatan-pendekatan untuk pemecahan masalah, misalnya gambargambar, diagram, sistem koordinat, vektor, dan transformasi. Dengan mempelajari geometri dapat menumbuhkan kemampuan berfikir logis, mengembangkan kemampuan memecahkan masalah dan pemberian alasan. Dalam geometri terdapat unsur penggunaan visualisasi, penalaran spasial dan pemodelan.

Hal ini menunjukkan bahwa kemampuan spasial merupakan tuntutan kurikulum yang harus diakomodasi dalam pembelajaran di kelas. Dalam kurikulum nasional di Indonesia, dari tingkat sekolah dasar sampai perguruan tinggi dituntut untuk dapat menguasai materi geometri bidang dan geometri ruang yang notabene juga membutuhkan kemampuan spasial. Tujuan pembelajaran geometri adalah agar siswa memperoleh rasa percaya diri mengenai kemampuan matematikanya, menjadi pemecah masalah yang baik, dapat berkomunikasi secara matematik, dan dapat bernalar secara matematik. Sedangkan menurut Budiarto dalam Rendik Widiyanto dan Badiatur Rofiah (2012:10) menyatakan bahwa tujuan pembelajaran geometri adalah untuk mengembangkan kemampuan berpikir logis, mengembangkan intuisi keruangan, menanamkan pengetahuan untuk menunjang materi yang lain, dan dapat membaca serta menginterpretasikan argumen-argumen matematik.

Berdasarkan dari Ide Gardner dalam Emilia Sarno (2012:5) bahwa antara kecerdasan spasial dengan geometri mempunyai keterkaitan karena kecerdasan spasial bermanifestasi dengan geometri, serta menurut Piaget (1981) menunjukkan bahwa adanya korelasi antara kecerdasan spasial dan prestasi dalam matematika.

Berdasarkan pada studi yang dilakukan oleh Bishop (1980) dalam Rendik Widiyanto dan Badiatur Rofiah (2012:5) menemukan adanya hubungan antara pemecahan masalah matematika dengan kemampuan visual spasial. Dalam mempelajari peran kecerdasan spasial terhadap prestasi belajar matematika, Smith (1980) menyimpulkan bahwa antara kecerdasan spasial dengan konsep matematika taraf tinggi terdapat hubungan yang positif, tetapi kurang mempunyai hubungan dengan konsep matematika taraf rendah seperti hitungan. Penggunaan contoh spasial seperti membuat bagan, dapat membantu anak menguasai konsep matematika.

\section{SIMPULAN}

Kemampuan spasial siswa SMP yang keceradasannya spasial dalam memecahkan masalah geometri ruang yakni dengan cara setiap siswa mampu berusaha mengembangkan kemampuan penginderaan spasialnya yang sangat berguna dalam memahami relasi dan sifat-sifat dalam geometri untuk memecahkan masalah matematika dan masalah dalam kehidupan sehari-hari. Serta dengan menggunakan kecerdasan spasialnya siswa mampu menujukan pengenalan sifat dari berbagai objek pada saat mereka memandang. Pengenalan tersebut mencakup berbagai bentuk geometri, huruf, angka dan sebagainya. Sehingga dengan adanya proses pengenalan sifat tersebut siswa mampu memproses bentuk-bentuk yang abstrak kemudian digambarkan dalam bentuk yang konkrit.

Kemampuan spasial siswa SMP yang kecerdasannya logika dalam memecahkan masalah geometri ruang yakni dengan mempelajari geometri dapat menumbuhkan kemampuan berfikir logis, mengembangkan kemampuan memecahkan masalah dan 
pemberian alasan. Serta dalam geometri juga terdapat unsur penggunaan visualisasi, penalaran spasial dan pemodelan.

\section{DAFTAR PUSTAKA}

Depdiknas, 2006, Kurikulum Tingkat Satuan Pendidikan (KTSP)

Efendi, Agus. 2005. Revolusi Kecerdasan Abad 21. Bandung: Alfabeta.

Gardner, Howard. 2009. Multiple Intelligences Arround The Word. JosseyBass: United States Of America

Hasyim, M. H. 2009. Tujuan Pendidikan dan Pengajaran di SMP dan MTs

Jasmine, Julia. 2012. Metode Mengajar Mulitiple Intelligences. Bandung: Nuansa Cendekia.

Mbagho, Hilaria Melania. 2012. Pemanfaatan Benda-benda Manipulatif untuk Pemahaman Konsep Geometri dan Daya Tilik Ruangan.

NCTM .2000. Principles and Standards for School Mathematics. United States of America: National Council of Teachers of Mathematics

Polya, G. 1973. How To Solve it. New Jersey: Princeton University Press.

Rynhart, Pavani. 2012. Importance. of Spatial Skill. Diakses $d i$ : http://proactiveplay.com/importance-ofspatial-skills/ (25-09-2013)

Sarno, Emilia. 2012. From Spatial Intelligence to Spatial Competences: The Results of Applied Geo- Research in Italian Schools. Diakses: http://www.rigeo.org/vol2no2/3.2.RIGEOOL.\%203.\%20NO.\%202.pdf （ 25-092013)

Suharnan. 2005. Psikologi kognitif. Surabaya: Srikandi.

Sujarwo, Anton. 2011. Proses Berpikir Siswa SMK dengan Kecerdasan linguisti, Logika Matematika, dan Visual Spasial dalam Memecahkan Masalah Matematika. Tesisi : pasca sarjana Unesa.
Tambunan, Marliah Siti. 2006. Hubungan Antara Kemampuan Spasial Dengan Prestasi Belajar Matematika. Diakses di: http://repository.ui.ac.id/contents/koleksi/ 2/ab7a1a844eb6a9a364b96be48eeffoc66 dc31a63.pdf. (25-09-2013)

Widiyanto, Rendik dan Badiatur Rofiah. 2012. Pentingnya Kecerdasan Spasial alam Pembelajaran Geometri. Diakses di: http://rendikwidiyanto.wordpress.com/201 2/11/07/pentingnya-kecerdasan-spasialdalam-pembelajaran-geometri/ (25-092013 